\title{
Gripo pamokos Lietuvoje ir gairès ateičiai
}

\author{
Alfredas Bagdonas ${ }^{1}$, Oksana Valentij ${ }^{2}$ \\ ${ }^{1}$ Kauno klinikinès ligoninès 1-asis vidaus ligų skyrius, ${ }^{2}$ LSMU MA Šeimos klinika
}

Reikšminiai žodžiai: gripas, pandemija, epidemiologija, komplikacijos, antivirusiniai vaistai, gydymas, profilaktika.

Santrauka. Gripas yra viena iš labiausiai paplitusių ir grẻsmingiausių üminių viršutinių kvėpavimo takų infekcinių ligų. Lietuvos miestuose epidemijos metu sergamumas pasiekia 20-50 proc., o liga pavojinga tuo, jog nepavyksta išvengti grèsmingu komplikacijų ir mirties atvejų. Kadangi Lietuvoje skiepijasi kritiškai mažai gyventojų, išvengti skausmingų gripo padarinių artimiausioje ateityje nepavyks. Apie tai būtina plačiau informuoti visuomenę. Straipsnyje aptariama gripo pandemijas sąlygojantys veiksniai, 2009-2011 metų laikotarpio epidemiologinè gripo situacija Lietuvoje, gresiančios gripo komplikacijos, gydymo ir profilaktikos ypatumai, skiepų svarba apsisaugoti nuo gripo.

Pirmą kartą gripas buvo paminėtas 412 m. pr. Kr. Hipokrato. Būtent tada medicinos tèvas aprašè ligą, kurios simptomai (staiga prasidejjęs karščiavimas, galvos, raumenų bei gerklès skausmas) labai panašūs i gripo. Liga išsiskyrè tuo, kad ja greitai užsikrèsdavo kiti žmonès. Jeigu susirgdavo bent vienas asmuo, po kelių dienų ligonių jau buvo dešimtys, o po savaitės - šimtai. Kildavo tikros epidemijos, kurios minimos seniausiuose istoriniuose metraščiuose [3, 4]. Didžiausia ir liūdnai pagarsejjusi ispaniškojo gripo pandemija kilo 1918 metais, ją sukèlè A (H1N1) virusas. Nuo šio gripo nukentèjo apie 20-40 proc. visų žemès gyventojų. Per dešimt mènesių gripo pandemija išplito visame pasaulyje. Per dvejus metus mirè apie $20 \mathrm{mln}$. žmonių, remiantis kai kuriais duomenimis, skaičius galejo siekti netgi 40-50 mln., t. y. 2,5 proc. žemės gyventojų. Idomiausia tai, kad nuo ispaniškojo gripo ir/ar jo sukeltu komplikacijų mirdavo suaugusieji, o vaikai ir senyvo amžiaus žmonès ligai buvo atsparūs [5].

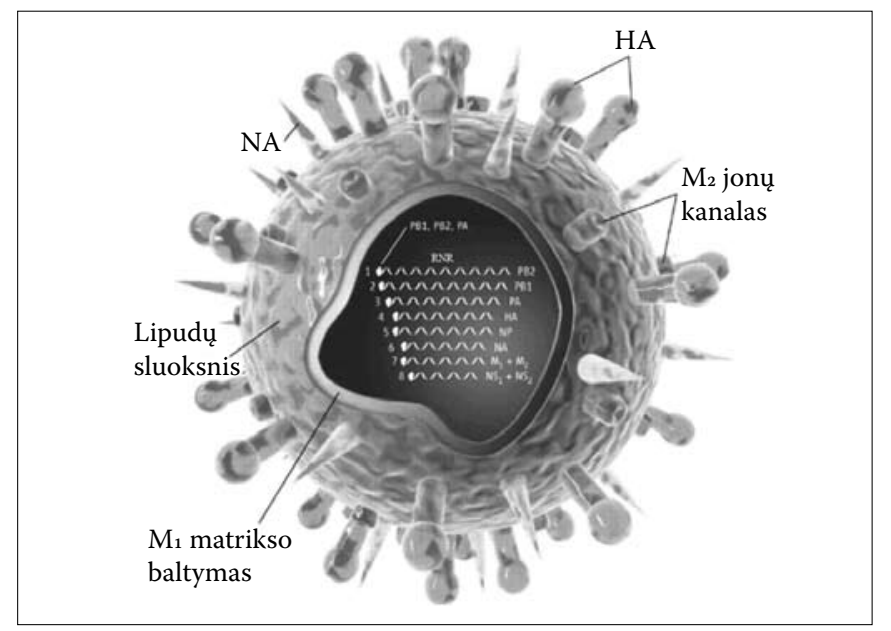

1 pav. Gripo viruso dalelès modelis [10]
1957-1958 metais išplito A (H2N2) viruso sukelta azijietiško gripo pandemija, per kurią mirè apie $2 \mathrm{mln}$. žmonių. 1968-1969 metais A (H3N2) virusas, sukèlęs Honkongo gripo pandemiją, nusinešè apie $1 \mathrm{mln}$. žmonių gyvybes.

\section{GRIPO VIRUSAS}

Gripo sukèlejas (gripo virusas) buvo atrastas 1931 metais Shope, o virusologai Smith, Andrews ir Laidlaw 1933 metais identifikavo A grupès virusą. Po trejų metų Francis atrado B grupés virusą. 1947 metais Taylor pirmasis nustatè $C$ grupès virusą.

Gripo virusas priklauso Orthomyxoviridae šeimai ir skiriamas i tris gentis: Influenzavirus $A$, Influenzavirus $B$ ir Influenzavirus $C[6,7]$. B ir $C$ tipo gripo virusai sukelia tik pavienius ir ribotus susirgimu protrūkius ir niekada nesukelia gripo pandemijos [7], pagrindinis sezoninio gripo ir pandemijų kaltininkas yra A tipo gripo virusas [7]. Virusas turi 8 segmentų vienagrandès RNR genomą. Influenzavirus $B$ ir Influenzavirus $C$ nustatomi žmonèms. Influenzavirus $A$ pagal glikoproteinu (hemagliutinino ir neuraminidazès) antigenines savybes dar skiriami ì potipius. Influenzavirus $A$ viruso struktūrą sudaro hemagliutininas (HA), neuraminidazè (NA), nukleoproteinai, $M_{1}$ (matrikso baltymas), $\mathrm{M}_{2}$ (jonų kanalas), nestruktūriniai baltymai $\left(\mathrm{NS}_{1}, \mathrm{NS}_{2}\right)$, polimerazių kompleksas ( $\mathrm{PA}, \mathrm{PB}_{1}$, $\mathrm{PB}_{1}-\mathrm{F}_{2}$ ir $\mathrm{PB}_{2}$ ) (1 pav.). Polimerazių kompleksas koduoja struktūrinius baltymus, atsakingas už viruso reprodukciją ir virulentiškumą, gali būti naudojamas diagnostikos tikslu (PGR, antigeno nustatymas) [7, 8, 9].

HA ir NA yra išoriniai viruso antigenai. HA gamina apsauginius antigenus, be to, užtikrina viruso prisitvirtinimą prie makroorganizmo ląstelès. NA receptoriai suardo ir 
Lentelè. Gripo atvejų skaičius 2009-2011 m. laikotarpiu

\begin{tabular}{|c|c|c|c|c|c|}
\hline \multirow[t]{2}{*}{ Metai } & \multicolumn{3}{|c|}{ Susirgimų gripu skaičius } & \multirow{2}{*}{$\begin{array}{l}\text { Mirusiųjų } \\
\text { skaičius }\end{array}$} & \multirow{2}{*}{$\begin{array}{l}\text { Rodiklis } \\
10 \text { tūkst. gyv. }\end{array}$} \\
\hline & Iš viso & Moterys & Vyrai & & \\
\hline 2009 & 68750 & 33414 & 35336 & 20 & 203,67 \\
\hline 2010 & 3385 & 1640 & 1745 & 7 & 10,14 \\
\hline 2011 & 41596 & 20371 & 21225 & 21 & 126,55 \\
\hline
\end{tabular}

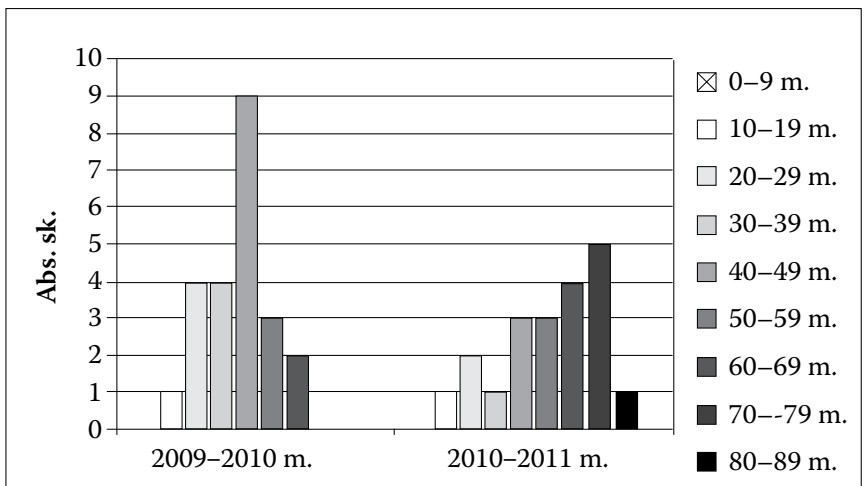

2 pav. Mirčių pasiskirstymas pagal amžiaus grupes dvieju paskutinių gripo sezonų metu

skatina viruso išsiskyrimą iš infekuotos ląstelès po ịvykusios viruso replikacijos. Antikūnai prieš HA lemia pagrindinị imunitetą prieš virusą, o antikūnai prieš NA užkerta kelią viruso plitimui organizme ir slopina uždegimo procesus. Serologiškai buvo išskirta 15 HA ir 9 NA baltymų, kuriuos atitinkamai pavadino $\left(\mathrm{H}_{1}, \mathrm{H}_{2}\right.$ ir t. t. bei $\mathrm{N}_{1}, \mathrm{~N}_{2}$ ir t. t.) $[7,8]$. Ligą sukelia tik $\mathrm{H}_{1}, \mathrm{H}_{2}$ ir $\mathrm{H}_{3}$ deriniai su $\mathrm{N}_{1}$ ir $\mathrm{N}_{2}$ [6].

Nuo seno žinoma, kad gripo virusas dažnai mutuoja. Pokyčiai vyksta išoriniuose viruso antigenuose, t. y. hemagliutinine ir neuraminidazeje. Toks evoliucijos mechanizmas užtikrina viruso išlikimą. Naujai susidariusių padermių virusai, atvirkščiai nei jų pirmtakai, specifiniais antikūnais nesurišami. Yra du gripo viruso antigenų kitimo būdai: antigenų dreifas (angl. drift) (paviršiaus antigenų taškinès mutacijos, dèl kurių susidaro naujos viruso potipių padermès) bei antigenų poslinkis (angl. shift) (mutacija, dẻl kurios pasikeičia genomo segmento struktūra).

Antigenų dreifas sukelia santykinai nereikšmingus, smulkius NA ir HA antigenų pokyčius. Tokios mutacijos kartojasi kas 2-3 metus, jos įvyksta spontaniškai. Mutavęs virusas, cirkuliuodamas visuomenėje, dažnai sukelia epidemijas.

Reikšmingas ir pavojingas antigenų mutacijas išprovokuoja antigenų poslinkis. Tai lemia susidarymą visiškai naujų gripo viruso potipių, prieš kuriuos žmogaus organizmo imuninè sistema bejègè. Tai savo ruoštu sąlygoja pandemiją bei didelị mirtingumą. Antigenų poslinkiai būdingiausi A tipo gripo virusams ir gali kartotis kartą per dešimtmeti [7, 11-14].

\section{EPIDEMIOLOGIJOS YPATUMAI}

Pagrindinis gripo infekcijos šaltinis - sergantis žmogus. Tačiau gamtoje yra ir gripo viruso rezervuarų - žinduoliai (kiaulès, arkliai) bei paukščiai (naminiai, laukiniai); jie svarbūs naujų žmogaus gripo viruso potipių forma- vimuisi. Sergantis gripu kitą asmenį užkrečia oro lašiniu būdu kvėpuodamas, kalbėdamas, rèkdamas, kosėdamas ar čiaudèdamas. Inkubacinis gripo periodas vidutiniškai trunka iki 48 valandų, rečiau - 72 valandas $[1,2]$. Šiuo laikotarpiu sergantis asmuo saugus, t. y. neišskiria arba visai neišskiria viruso $[15,16]$. Gripo epidemijos kyla sezoniškai ir priklauso nuo šalies geografinès padèties, dažniausiai šaltuoju metų laiku, ligos protrūkiai registruojami nuo gruodžio iki kovo mènesio. Lietuvoje gripo epidemijos dažniausios sausio-kovo mènesiais.

Idomiausia ir viena iš didžiausių mįslių yra ta, kad didžiąją laiko dalị gripo virusas populiacijoje necirkuliuoja. Epidemija trunka apie 1-3 ménesius, po to gripo virusas „dingsta“. Kur jis cirkuliuoja likusị laiką, kur ir kaip ịvyksta antigenų dreifas, iki šiol tiksliai neaišku. Labiausiai tikètina hipotezè - gripo virusas cirkuliuoja pusiaujo zonoje, kur sergamumas gripu registruojamas ištisus metus. Kaip minèta, dèl viruso genų mutacijų kylančios pandemijos yra neprognozuojamos ir nenuspejamos, o jụ pasekmès gali būti labai sunkios, mirtingumas didelis [17].

Gripo atvejų statistiniai rodikliai, remiantis Lietuvos užkrečiamųjų ligų ir AIDS centro duomenimis apie gyventojų sergamumą užkrečiamosiomis ligomis, pateikti lentelëje. Mirčiu pasiskirstymas pagal amžiaus grupes pateiktas 2 paveiksle [18].

Analizuojant mirties nuo gripo atvejus, nustatyta, jog didžioji dalis mirusiųjų (71,4 proc.) nebuvo pasiskiepiję specifine gripo vakcina, o apie likusiųjų skiepijimą duomenų nẻra [18]. Tai skatina manyti, jog nuo gripo pasiskiepiję asmenys gripu nesusirgo, o jei susirgo, tai ligos eiga buvo lengvesnè, grèsmingų komplikacijų rizika mažesnè. Sergamumas gripu 2011-2012 m. sezonu Lietuvoje buvo mažas, galutinių sergamumo ir mirtingumo analizès duomenų dar nèra.

Pagrindinis veiksnys, lemiantis epidemijos plitimą bei sunkumą, - populiacijos imuniteto laipsnis. Jeigu atsiranda virusas su visiškai naujais antigenais, prieš kuriuos nèra antikūnų, arba populiacijos imunitetas menkas, įvyksta ligos protrūkis. Tačiau, jeigu antikūnų prieš virusą populiacijoje visiškai nèra, tai paskatina epidemiją plisti visame pasaulyje ir gali kilti pandemija. Tokios pandemijos „bangos" gali tęstis keletą metų, kol populiacijoje susiformuoja geras imuninis atsakas.

\section{GRESIANČIOS KOMPLIKACIJOS}

Kaip sako dauguma specialistų, gripas nèra toks baisus kaip jo sukeliamos komplikacijos, o ju gripas gali sukelti iš tiesų daug. Susirgus gripu, pirmiausia pažeidžiamas kvėpavimo takų virpamasis epitelis, kurio pagrindinè fiziologine funkcija - apsaugoti ir pašalinti iš kvèpavimo takų galimą sukèlejją. Dèl pažeidimų virpamasis epitelis praranda savo apsaugines savybes ir negali efektyviai apsaugoti makroorganizmo nuo tolesnio sukèlëjo plitimo ir antrinès infekcijos. Be to, dèl viruso sąlygojamos citolizès išsiskiria labai daug prouždegimo citokinų ir chemokinų. Ši „citokinų audra“ sukelia ir kitų organų bei kraujagyslių pažeidimą, su ja siejamas ženklus širdies ir kraujagyslių sistemos ligu (infarkto, insulto) padažnejjimas vyresnio amžiaus asmenų grupeje gripo epidemijos metu. 
Gripo sukeliamos komplikacijos vystosi sparčiai, gali apimti visas gyvybiškai svarbias organizmo sistemas, būtent dèl to ši liga tokia nenuspèjama.

Gripo sukeliamos komplikacijos:

- Kvèpavimo sistemos (otitas, sinusitas, rinitas, tracheitas, pirminé gripinè pneumonija, antrinè bakterinè pneumonija, pleuros empiema, plaučių abscesas, ūminis kvépavimo nepakankamumas);

- Širdies ir kraujagysliuc sistemos (miokarditas, perikarditas, širdies nepakankamumas);

- Kraujodaros sistemos;

- Genitourinarinès sistemos (glomerulonefritas);

- Nervų sistemos (meningitas, meningoencefalitas, encefalitas, neuritas, neuralgija, poliradikuloneuritas);

- Raumenuc sistemos (miozitas).

Pagrindinès gripo komplikacijų grupès:

- Komplikacijos tiesiogiai susijusios su ligos eiga (hemoraginé plaučių edema, ūminis kvépavimo nepakankamumas, meningitas, serozinis meningoencefalitas, toksinis šokas);

- Komplikacijos, su beprasidedančia antrine bakterine infekcija (pneumonija, otitas, sinusitas, glomerulonefritas, pūlinis meningitas, sepsinès būklès).

Gripo bakterinès komplikacijos paprastai vystosi kiek vèliau, kai paciento būklè pagerèja, sumažejja karščiavimas, pacientas lyg ir sveiksta nuo gripo. Tada prasideda antroji karščiavimo banga, ir būklè vèl ima blogèti.

Pirminè virusinè/gripinè pneumonija reta, tačiau viena sunkiausių komplikacijų, kurią tiesiogiai sukelia gripo virusas. Ši grèsminga komplikacija dažniau nustatoma gripo pandemijų metu ir, nepaisant šiuolaikinio gydymo, daugiau kaip 40 proc. hospitalizuotu pacientų neišvengiamai miršta. 2009 metų A tipo gripo viruso epidemijos metu Meksikoje iš 18 hospitalizuotu dèl pirminès gripinès pneumonijos (vèliau verifikuotos kaip H1N1 potipio) dešimčiai pacientų per pirmąsias 24 valandas ligoninejje išsivystė respiracinis distresas ir, nepaisant taikytuc visų šiuolaikinio gydymo priemonių, 7 pacientai mirè [28].

Gripinė pneumonija paprastai prasideda per pirmąsias dvi sirgimo paras, iš pradžių kosulys neproduktyvus, vẻliau skrepliuojama kraujingais skrepliais, progresuoja kvejpavimo nepakankamumas, išryškejja sunki intoksikacija, difuzinė mialgija, atkaklus karščiavimas. Nors ligos pradžioje nenustatoma aiškių radiologinių pneumonijos požymių, vẻliau pastebima plaučių edemai ar respiraciniam distresui būdingų radiologinių pokyčių. Ženklus laktatdehidrogenazès ir kreatinfosfokinazès kiekio padidèjimas laikomas blogos prognozès požymiu. Pacientų prognozei lemiamos reikšmès turi anksti pradètas gydymas antivirusiniais vaistais, tinkama hidratacija, oksigenoterapija bei nepavèluota intubacija/ ventiliacija. Pirmine virusine pneumonija anksčiau dažniau susirgdavo vyresnio amžiaus asmenys, ypač sergantys lètinėmis plaučiu ar širdies ligomis, tačiau, remiantis naujausiais sergamumo duomenimis, ligos aukomis tampa jauni asmenys, iki tol buvę visiškai sveiki [20, 21].

Antrinė bakterinè pneumonija - dažniausia komplikacija, dèl kurios pacientą tenka hospitalizuoti. Kadangi pneumonija vystosi dèl viruso pažeisto virpamojo epitelio bei nusilpusio imuninio atsako, jos eiga sunkesnè, didesnè komplikacijų ir blogos prognozès tikimybè nei sergant iprasta visuomenèje igyta pneumonija. Svarbu tai, jog, be tipinių, dažniausiai pasitaikančių visuomenèje igytos pneumonijos sukèlèju (Streptococcus pneumoniae, Haemophilus influenzae ir kitu gramneigiamu enterobakterijų), labai didelè Staphylococcus aureus (iskaitant ir MRSA padermes) tikimybè. Todèl antrinei pneumonijai gydyti empiriškai pasirenkamas antibiotikas turètų veikti ir ši grèsmingą sukèlèją. Antrinè bakterinè pneumonija prasideda staiga, maždaug po 5-7 parų nuo susirgimo gripu pradžios, pacientas vèl pradeda karščiuoti, atsiranda pūlingas skrepliavimas, dusulys. Esant stafilokokinei pneumonijai, ligos eiga dažniau sunki, greitai progresuojanti, o intrahospitalinis mirtingumas gali siekti 33 proc. [7, 20-23]. Kasmet nuo gripo ir jo sąlygotuc komplikacijuc JAV miršta 36 tūkst. asmenų ir daugiau kaip 200 tūkst. hospitalizuojama. Didžiausias mirtingumas (iki 90 proc. visų mirties atvejų) vyresnių kaip $65 \mathrm{~m}$. amžiaus asmenų grupẻje ne tik nuo plaučių ligų komplikacijų, bet ir dramatiško lètinių širdies ir kraujagyslių ligu pablogèjimo. Todèl šios amžiaus grupès asmenims būtina skiepytis.

Viena iš problemų, ypač išryškejjusių 2009-2010 m. gripo pandemijos metu, yra ta, jog nèra greitos ir klinikinejje praktikoje plačiau prieinamos gripo viruso laboratorinès diagnostikos. Paaiškejjo, jog dažnai taikytų greito (rezultatas gaunamas per valandą) gripo viruso antigeno nustatymo testai yra tik vidutinio (63 proc.) jautrumo nustatant sezoninio gripo virusą, o jų jautrumas identifikuojant pandemini H1N1 gripo virusą nepriimtinai menkas. Kiti tyrimo metodai užima daugiau laiko arba sunkiau prieinami ir brangūs.

Bendradarbiaujant JAV ir Didžiosios Britanijos genetikams bandyta išsiaiškinti, kodèl gripo virusas vienus sunkiai susargdina ir/ar nužudo, o kiti perserga lengvai. Išanalizavę studijų rezultatus, tyrejjai paskelbė, jog atrado geną, atsakingą už žmogaus reakciją i gripo viruso sukeltą infekciją - IFITM3 (interferoną indukuojantys transmembraniniai baltymai; angl. interferon inducible transmembrane protein family members). Mokslininkai teigia: jeigu ląsteleje yra didelis kiekis baltymo, koduojančio IFITM3, tai viruso plitimas sutrikdomas, o jeigu IFITM3 kiekis mažas, virusas greičiau ir lengviau replikuojasi, greitai plinta ir sukelia sunkesnę ligą bei komplikacijas. Šis atradimas ateityje gali padèti sukurti efektyvesnius vaistus bei vakciną nuo gripo [24].

\section{GYDYMO YPATUMAI}

Gripui gydyti skiriami antivirusiniai vaistai, profilaktikai - pokontaktiné profilaktika antivirusiniais vaistais, skiepijimas ir gripo viruso plitimą ribojančios priemonès. Remiantis Sveikatos apsaugos agentūros (angl. Health Protection Agency, HPA) pateiktomis gydymo rekomendacijomis, dabar gripui gydyti skirtini tik neuraminidazès inhibitoriai, oseltamiviro bei zanamiviro preparatai, kurie veikia Influenzavirus $A$ ir Influenzavirus B. Anksčiau Lietuvoje plačiai vartoti nukleozidu analogai - rimantadinas ir amantadinas - dèl riboto veiksmingumo bei sparčiai didejjančio gripo virusų atsparumo šiems vaistams rutininiam gripo gydymui nerekomenduojami. Lietuvoje prieš keletą metų gripo epidemijos laikotarpiu buvo atliktas klinikinis tyrimas, kuriuo vertintas oseltamiviro efektyvumas. Tyrime dalyvavo 13-97 metu asmenys, kuriems pirmieji gripo simptomai pasireiške prieš 36 valandas. Tiriamieji buvo suskirstyti i dvi grupes: vieni vartojo po $75 \mathrm{mg}$ oseltamiviro du kartus 
per parą 5 paras, o kiti - placebą du kartus per parą 5 paras. Ivertinus tiriamųjų būklę po 12 val. paaiškejjo, kad oseltamivirą vartoję asmenys jautèsi geriau nei placebo grupès, o po 24 val. gydymo oseltamivirą vartoję pacientai mažiau karščiavo, jiems silpniau skaudejo galvą ir raumenis [26]. Antivirusinis gydymas turi būti pradedamas kuo anksčiau, bet ne vèliau kaip per 48 valandas nuo ligos pradžios. Preparato pasirinkimas priklauso nuo rizikos veiksnių (t. y. kokiai rizikos grupei priklauso asmuo), klinikinès būklès, kokie antivirusiniai preparatai jau buvo vartoti anksčiau, kokios gripo padermès cirkuliuoja, koks jų atsparumas, dabartinès epidemiologijos.

Profilaktiškai vartojant antivirusinius vaistus išvengiama susirgimo gripu, bet ne ikiklinikinès jo formos. Toks asmuo lieka infekcijos šaltinis. Todèl chemoprofilaktika nèra veiksminga priemonè nutraukti viruso perdavimą ir negali pakeisti skiepijimo, kuris tebèra pagrindine gripo valdymo ir profilaktikos priemonè. Nors nè viena vakcina 100 proc. neapsaugo nuo susirgimo, tik skiepai gali iš esmès pakeisti sergamumo, sunkių komplikaciju ir mirties nuo gripo statistiką. Nerimą kelia tai, jog Lietuvoje plinta neigiamas požiūris ị skiepijimąsi nuo gripo. Žiniasklaidoje skleidžiami ịvairūs mitai apie vakcinų neveiksmingumą, didelị šalutinị poveikị, propaguojantys skiepijimą neretai apkaltinami farmacijos kompaniju pelno interesu atstovavimu. Dèl to Lietuvoje per pastaruosius kelerius metus kasmet nuo gripo pasiskiepija tik apie 6 proc. gyventoju. Remiantis PSO duomenimis, mūsų šalis pagal ši rodiklị užima vieną paskutinių vietų Europos Sąjungoje. Kitose Europos valstybèse (Didžiojoje Britanijoje skiepijasi apie 75 proc., Niderlanduose - apie 80 proc. gyventojų), kur skiepai yra ịprastas apsisaugojimo nuo gripo būdas, mirtingumas nuo gripo komplikacijų daug mažesnis.

JAV plačiai naudojama trivalentė intranazalinè gyvo susilpninto gripo viruso vakcina, o 2013-2014 metu gripo sezonui planuojama sukurti keturvalentę gyvo susilpninto gripo viruso vakciną. Jomis bus skiepijami visi sveiki asmenys nuo 2 iki 49 metú amžiaus [27].

PSO paskelbė prioritetines grupes asmenų, kurie turètų būti skiepijami:

1. Šešių mènesių ir vyresni vaikai, sergantys lètinèmis širdies ar plaučių, medžiagų apykaitos ar inkstų ligomis, lètine kepenų liga, lètinėmis nervų ligomis ar turinčius imuniteto nepakankamumą;

2. Senyvo amžiaus žmonès, peržengę šalyse nustatytą amžiaus ribą, nepriklausomai nuo kitų rizikos veiksnių;

3. Nèščios moterys;

4. Sveikatos priežiūros darbuotojai, ìskaitant dirbančius senelių globos ar neigalių žmonių namuose;

5. Kiti, nurodomi valstybinès duomenų bazès ir kuriuos skiepyti yra galimybių.

\section{APIBENDRINIMAS}

Gripas yra viena iš labiausiai paplitusių ir grèsmingiausių ūminių viršutinių kvėpavimo takų infekcijų. Lietuvos miestuose epidemiju metu sergamumas pasiekia 20-50 proc., o liga pavojinga tuo, jog nepavyksta išvengti grèsmingų komplikacijų ir mirties atvejų. Dažniausiai pasitaikanti sunki gripo komplikacija - antrinè bakterinè pneumonija, retesnè, bet daugumai hospitalizuotu pacientų mirtina
- pirminė gripinė pneumonija. Šių pacientu prognozè labiausiai priklauso nuo laiku nustatytos diagnozès, nepavèluoto hospitalizavimo, adekvataus gydymo antibiotikais bei anksti skirtų antivirusinių vaistų. Didžiausias mirtingumas nuo gripo ir jo sukeliamų komplikacijų yra vyresnių nei 65 m. asmenu grupejje. Pagrindinis gripo ir jo komplikaciju profilaktikos būdas - skiepijimas. Kadangi skiepijimosi mastas Lietuvoje yra kritiškai mažas, išvengti skausmingu gripo padarinių artimiausioje ateityje nepavyks. Apie tai būtina plačiau informuoti visuomenę, didinti pilietinès atsakomybès suvokimą, nes nepalankų požiūrị i skiepus dažniausiai lemia žinių apie skiepus stoka. Daugiau dèmesio reikètų skirti tikslinių populiacijos grupių - sveikatos priežiūros darbuotojų ir tèvų - mokymui.

\section{LESSONS OF INFLUENZA IN LITHUANIA AND GUIDELINES FOR THE FUTURE}

ALFREDAS BAGDONAS ', OKSANA VALENTIJ ${ }^{2}$

1 KAUNAS CLINICAL HOSPITAL, FIRST DEPARTMENT OF INTERNAL DISEASES 2 HOSPITAL OF LITHUANIAN UNIVERSITY OF HEALTH SCIENCES KAUNO CLINICS, FAMILY MEDICINE CLINIC

Keywords: influenza, pandemic, epidemiology, complications, antiviral medications, treatment, prevention.

Summary. Influenza is one of the most common and life-threatening of acute upper respiratory tract infections. During epidemic in Lithuanian cities morbidity reaches 20-50 pct., flu is a severe condition, because sometimes there is no possibilities to avoid/prevent threatening complications and even death. Whereas extent of vaccination in Lithuania is critical low, prevent the painful consequences of influenza in the near future will fail. So society must be widely informed about that. In the article discusses Influenzavirus variability causes, flu epidemics and pandemics influencing factors, epidemiological situation in Lithuania during 2009-2011 period, also mentions/referred about the imminent complications of influenza that effect vital body systems, of prevention and treatment features, and the importance of flu vaccination.

\section{LITERATŪRA}

1. Influenza: Viral Infections: Merck Manual Home Edition". Merck. Retrieved 2008-03-15;

2. Eccles R. Understanding the symptoms of the common cold and influenza Lancet Infect Dis. 2005 Nov; 5 (11): 718-25.

3. Martin, P; Martin-Granel E (June 2006). "2,500-year evolution of the term epidemic". Emerg Infect Dis 12 (6): 976-80. doi:10.3201/eid1206.051263. PMID16707055.

4. Hippocrates; Adams, Francis (transl.) (400 BCE). "Of the Epidemics". Retrieved 2006-10-18.

5. Christina E. Mills, James M. Robins \& Marc LipsitchTransmissibility of 1918 pandemic influenza Nature 432, 904-906 (16 December 2004) doi:10.1038/ nature03063.

6. Cox NJ, Subbarao K: Global epidemiology of influenza: Past and present Annu Rev Med 2000; 51: 407-421.

7. Treanor JJ: Influenza virus. In: Principles and Practice of Infectious Diseases. Vol. 2. Mandell GL, Bennett JE, Dolin R (Eds). Philadelphia, PA. Elsevier, 2005, pp 2060-2085;

8. LaForce FM, Nichol KL, Cox NJ: Influenza:Virology, epidemiology, disease, and prevention.Am J Prev Med 1994; Suppl): 31-44.

9. Taubenberger JK: The origin and virulence of the 1918 "Spanish" influenza virus. Proc Am PhilosSoc 2006; 150:86-12.

10. Illustration:Chris Bickel/Science. Reprinted with permission from Science Vol.312, page 380 (21 April 2006)@ 2006 by AAAS.

11. Monto AS: Epidemiology of influenza. Vaccine 2008; 26 (Suppl 4):D45-D48.

12. Stephenson I, Zambon M: The epidemiology of influenza. Occup Med (Lond) 2002; 52:241-247.

13. Cannell JJ, Zasloff M, Garland CF, et al: On the epidemiology of influenza. Virol J 2008; 5:29 